\author{
Gopala Ganesh, Ph.D. \\ Department of Marketing \\ College of Business Administration \\ University of North Texas \\ P.O. Box 311396 \\ Denton, TX 76203-1396 \\ and \\ Audhesh K Paswan, Ph.D. \\ (Contact author) \\ Department of Marketing \\ College of Business Administration \\ University of North Texas \\ P.O. Box 311396 \\ Denton, TX 76203-1396 \\ Tel: 940-565-3121 \\ Fax: 940-565-3837 \\ e-mail: paswana@unt.edu
}

Revised on

July 30, 2007

For

Journal of Business Research

Special Issues on Advances in Spreadsheet and Database Training 
Teaching Basic Marketing Accountability using Spreadsheets: An Exploratory Perspective

\begin{abstract}
Extant literature suggests that a key problem with marketing is a lack of accountability and a possible way of improving the situation is to use spreadsheets to inculcate marketing accountability among future marketing executives. This study attempts to enhance our understanding of how to impart spreadsheet skills and encourage an accountability mind set among undergraduate marketing students by focusing on a course called Marketing and Money. Assessment data indicate that the course, which captures the spirit of the behavioral model of learning, does in fact enhance student's spreadsheet skill in a consistent manner. In addition, the analysis suggests that in order to increase student's self efficacy, instructors ought to try to make the course perceptually more useful rather than try to reduce its difficulty.
\end{abstract}




\section{Teaching Basic Marketing Accountability using Spreadsheets: An Exploratory Perspective}

"Marketing accountability has emerged as a subject of interest in both practitioner and academic marketing literature.." (Baker and Holt 2004, p 557). The idea is to incorporate finance and accounting concepts into marketing decisions, i.e., making marketing more measurable. Although importance of the marketing - finance interface has been acknowledged in the past (cf. Moorman and Rust 1999), of late it has gained increased momentum (Baker and Holt 2004). This was highlighted by articles in a special edition of Journal of Business Research edited by Zinkhan and Verbrugge (2000a). Different authors have focused on different aspects of the interface, e.g., advertising expenditure and earnings (Graham and Frankenburger 2000); marketing and bottom line (Ambler 2000a, 2000b; Shaw and Mazur 1997); and marketing and shareholders interest (Doyle 2000; Kumar et al. 2000; and McDonald et al. 2000). Zinkhan and Verbrugge (2000b) lament the lack of research attention given to marketing's relationship with firm performance or shareholder value. Seth and Sisodia (2002) suggest that a fundamental problem with marketing is a lack of accountability. Others argue that one reason for the minimal presence of marketing in the boardroom is that marketers have failed to demonstrate a definitive linkage between marketing activities, costs, and shareholder value (Ambler 2003; Doyle 2000; and Simms 2003). Baker and Holt (2004) identify several constituents, e.g., educators, academics, consultants, and practitioners, who may have contributed to this lack of accountability, and suggest an activity based approach to effective knowledge transfer. These studies have more than emphasized the importance of infusing financial accountability into the marketing profession.

So how do we infuse accountability into marketing education? Educators such as Dembeck and Stout (1997) and Lilien et al. (1998) have advocated the use of spreadsheet based 
decision models into marketing classes. They argue that such use of spreadsheet based decision models enhance managerial decision making by enhancing consistency, decision options, group decision making, and mental models (Lilien et al. 1998). However, despite the fact that spreadsheets have been around and their usage in decision making is also not new (cf. Black et al. 2005; Dembeck and Stout 1997; Hwarng 2001; Lilien et al. 1998; Palocksay and Markham 2002; Sosin et al. 2004; Yi and Davis 2003), very few have focused on use of spreadsheet to enhance marketing decision making or introducing accountability into the marketing function, in general. The spreadsheet based Marketing Engineering course by Lilien and Rangaswamy (Lilien et al. 1998) is targeted at the graduate students and focuses on more strategic marketing decisions. The current manuscript addresses a gap by focusing on a course that is targeted at the undergraduate students. The course uses spreadsheets in the context of marketing decisions and develops an accountability mindset among undergraduate marketing students. It is specifically designed for undergraduate students because they are often hired at the operational level and would most likely benefit from focus, objectivity and structure in learning the basics of managerial decision making. We believe that this is accomplished, in part, by the use of spreadsheets.

This paper starts out by examining the extant literature that have focused on the use of spreadsheet in an education and training context, and explores some of the theories that help develop a model of learning. This is followed by a narrative of the course context where spreadsheets are used and an explanation of assessment data collected over multiple semesters. Because of the descriptive nature of this study, no hypotheses are proposed. Instead, we simply provide details of the course, which uses Excel Spreadsheets, as a basis for imparting marketing accountability mindset among marketing students. Next is a description of how the course 
outcomes were assessed along with descriptive statistics to illustrate whether the course achieved its goals. In addition, correlation analyses are used to assess the relationships between different aspects of course outcomes. Finally, a discussion of the results, limitations and implications is presented.

\section{Extant Literature: Spreadsheet in Business Education}

Several authors have approached the use of spreadsheets in decision making from a very diverse perspective (cf. Black et al. 2005; Dembeck and Stout 1997; Hwarng 2001; Grossman 2006; Lilien et al. 1998; Markham and Palocksay 2006; Palocksay and Markham 2002; Sosin et al. 2004; Yi and Davis 2003). Sosin et al. (2004) examine the use of technology (including spreadsheets) in economics education. They found that the relationship between use of technology and student performance is not very clear. They suggest that it is not relevant to ask "whether to use or not use technology, but what technology to use in what manner" (Sosin et al. 2004, p 257). Yi and Davis (2003) develop and validate an observational learning model of computer software training and skill acquisition, which is discussed later in detail. Palocsay and Markham (2002) describe a course that uses spreadsheet in teaching decision support systems to IT students. Markham and Palocksay (2006) detail the use of spreadsheet in scenario analysis in a classroom. Hwarng (2001) employs a simulation in his course that uses the spreadsheet as a platform to teach student the nuances of simulation models. Grossman (2006) describes the process of spreadsheet engineering in a management science course. These examples illustrate the extensive use of spreadsheet for teaching and training purposes, primarily in OR/MS, decision sciences and MIS areas, with a focus on teaching the intricacies of the spreadsheet. 
Few of the extant studies have focused on use of spreadsheets to strengthen accountability in marketing functions. Lilien et al. (1998) advocate the use of spreadsheet-based models to make marketing decisions and have incorporated these in their 'marketing engineering' course package. They argue that without this shift in decision making approach, managers are limited to conceptual marketing and may suffer from responsibility bias and underrepresentation of measurable outcome variables. Spreadsheet based decision models provide focus and objectivity in managerial decision making, at the operational as well as strategic levels. Dembeck and Stout (1997) demonstrate that managers in a multinational firm can use spreadsheet software to arrive at an optimal solution to marketing problems such as what to produce and its mix. They suggest that "Decision analysis facilitated with a computerized spreadsheet can help financial managers sift through complex business opportunities and choose the most appropriate ones given their organization's objective(s)..” (p. 33). Black et al. (2005) demonstrate the usefulness of using Microsoft Excel in developing online survey instruments, and conclude that "Excel provides a useful, flexible, and easy to use Internet survey design program" (p 70). Thomas (2000) critiques extant financial reporting methods and suggests alternate performance measures. McDonald (2005) provides a conceptual framework for bringing clarity to measuring marketing effectiveness.

\section{Learning Models for Computer Skill Development:}

Yi and Davis (2003) state that industry in US spends about $\$ 57$ billion annually on formal training with enhancing computer skills as the most often cited content. Hence, the effectiveness of these training programs is extremely crucial. Yi and Davis (2003) take a detailed look at various learning models - e.g., traditional lecture based model of learning (Bolt et al. 2001; 
Compeau and Higgins 1995a; Johnson and Marakas 2000; Simon et al. 1996; and Simon and Werner 1996), computer-aided learning model (Gist et al. 1988, 1989), and self-study oriented model (Simon et al. 1996; Simon and Werner 1996), and based on their review of extant literature conclude that the behavioral model of learning results in better training outcomes than other models. They also contend that although various training methods relying on different learning models are used by industry, the pros and cons of these approaches are not well understood. Detailed discussions of training techniques and behavioral models of learning have been provided by studies such as Donovan and Radosevich (1999); Kozlowski et al. (2001); May and Kahnweiler (2000); and Salas and Cannon-Bowers (2001).

The underlying theoretical rationale for behavioral model of learning comes from social cognition theory (Bandura 1986) which essentially suggests that people learn by first watching someone else perform a target behavior and then reenacting it. The stages in this observational learning processes include attention, retention (cognitive registration), production (overt action to produce desired response), and motivation (favorable consequences of production leads to repeat performance). Yi and Davis (2003) use this social cognitive theoretical framework to develop a comprehensive model for the observational learning process and then test it empirically. They found that the observational learning process had a significant influence on both declarative knowledge and post-training self-efficacy, which, together with task performance constitutes the three most commonly used outcome variables (Colquitt et al. 2000). Yi and Davis (2003) expanded task performance into immediate and delayed task performance. Declarative knowledge captures a person's initial cognitive representation of the task, and knowledge about facts and things. It can be measured either by verbal specification of task objectives or by questions designed to assess a student's understanding of the key concepts (Yi and Davis 2003). 
Self-efficacy has been defined as "one's perceived performance capabilities for specific activity" (Kraiger et al. 1993, p. 320). Yi and Davis (2003) use post-training self-efficacy in their study. While self-efficacy and declarative knowledge capture the cognitive part of the training outcome, task performance captures the behavioral aspects. Extant studies have found a positive relationship between these three outcome variables (see the meta-analysis studies by Colquitt et al. 2000; Locke and Latham 1990; and Stajkovic and Luthans 1998; and Yi and Davis 2003 for a more recent empirical study).

Another relevant theoretical framework often used to explain the adoption of technology is Technology Adoption Model - TAM (cf. Davis 1986; 1989; 1993; Davis, Bagozzi, and Warshaw 1989; Venkatesh and Davis 1996) and it is based on the theory of reasoned action (Ajzen and Fishbein 1980; Fishbein and Ajzen 1975). The TAM framework is relevant because spreadsheet and its usage in decision making are seen as something that involves math and technology by business students in general and marketing students in particular and hence are approached with some fear and apprehension (Grossman 2006; Jordan et al. 1997; Papageorgiou 1996). Grossman (2006) also states that knowledge and use of spreadsheet for serious work is not easy.

TAM model (cf. Davis 1986; 1989; 1993; Davis, Bagozzi, and Warshaw 1989; Venkatesh and Davis 1996) includes two variables - perceived ease of use and perceived usefulness as determinants of behavioral intention and subsequent actual use. Venkatesh and Davis (1996) suggest that direct hands-on experience by users enhances system specific ease of use perception. In addition, both Davis (1989) and Venkatesh and Davis (1996) suggest that perceived ease of use is similar to self efficacy. 
Finally, consumer psychology literature under the rubric of means-end-chain or hierarchy of goals (Gutman 1982; Gutman 1997) suggests that beyond the task level determinants such as ease of use and usefulness, people are driven towards action by higher level goals and outcomes. Gutman (1997) proposes three levels of goals - action goals that are linked to the act itself, outcome goals associated with immediate effects of the action, and the highest level goals or consequences including the indirect effects of the outcome. Since its inception, the means-end-chain has been used to explain consumer behavior in varied context such as perception of soft drinks (Gutman 1997); US President (Bagozzi and Dabholkar (2000), Food retailing (Devlin, Birtwistle, and Macedo (2003); service employees (Pieters, Bottschen and Thelen 1998); and higher education (Gutman and Miaoulis 2003). This means-end-chain model has been investigated in a higher education context, resulting in the finding that it could be used to develop service positioning strategies (Gutman and Miaoulis 2003). These studies suggest that some of the outcome goals associated with education include competence (a direct outcome of the act itself) as well as higher order consequences such as success in life, jobs, and interviews. In our study, the design of the course and the pedagogical tools used allow the students to use the spreadsheets in marketing context. The case-let-based hands-on approach organized by modules that increasingly get more involved and/or difficult and the manageable smaller set activities to be completed in each block help students acquire direct experience. With this, students find it easy to use spreadsheets in marketing decisions and develop a sense of competence. They come to realize that use of such tools in marketing decisions puts them on a firmer ground than if they made these decisions based on gut-feeling and intuition. Repetition of this process during the semester helps them see that it is not that difficult. Success in solving the spreadsheet problems 
along with frequent feedback helps the students see the usefulness of the tool in marketing decision making and realize that it may be a good skill for their future.

Relying on these studies, we use perceived ease of use (or post use self efficacy) with different spreadsheet-intensive modules and perceived usefulness of the content knowledge covered in these to assess whether the pedagogy adopted in the course achieves its objectives, We believe that the perceived ease of use and usefulness of the various spreadsheet modules will make students see their benefits and hopefully encourage them to make more use of the spreadsheet in making marketing decision in future - either in other classes or in their work environment. In addition, we also looked at the students' perception of outcome benefits (i.e., task specific competence and success in life and jobs) resulting from the application of spreadsheet knowledge in marketing decisions.

These form the theoretical basis for the discussion of the context for this study, which is a course that relies on spreadsheets to impart data based decision making skills and an accountability mindset among undergraduate marketing students. In the next section, we present the details of the course.

\section{Study Context: Spreadsheets in marketing decision making}

The study context is a course called Marketing and Money (henceforth referred to as M and $\mathrm{M}$ ) taught at a major comprehensive American university in the Southwest. M and M is a required course for undergraduate Marketing students. It is scheduled to be taken immediately after the Marketing Principles course, but before advanced marketing courses and electives. M and $\mathrm{M}$ is intended to reinforce the content knowledge gained in basic accounting and mathematics classes and incorporate this knowledge within the context of marketing decisions to 
develop an accountability mind set among marketing students. Students typically come to this class having completed the mandatory sophomore-level MIS and Decision science classes that initially expose most of them to spreadsheets. $\mathrm{M}$ and $\mathrm{M}$ takes this further by relying heavily on Excel spreadsheets for computation of some of the commonly used marketing metrics,

The $\mathrm{M}$ and $\mathrm{M}$ course consists of 12 modules through which content knowledge is introduced and reinforced. Ten of these are concept modules and two are "How To" modules. The ten concept modules focus (M01) Percentages and Weighted Average, (M02) Balance Sheet and Income Statement, (M03) Channel Markups, (M04) Contribution and Breakeven, (M05) Product, (M06) Promotion, (M07) Price, (M08) Distribution, (M09) Net Present Value, and (M10) Decision under uncertainty. These concept modules are all structured alike: explanation of concepts interspersed with as well as followed by several one page case-lets from a collection of nearly 200 marketing math oriented case-lets, problems and teaching notes obtained from several colleagues at other universities. Some new case-lets were also specifically written for this class by the professor. All case-lets obtained from other sources were revised to fit to one page, updated (year, focal product etc.) and appended with specific questions intended to take the student towards the final answer, step-by-step. In a typical semester only about 50 of these caselets are used. This allows easy customization of the course from semester to semester. Therefore, there is no text book for this apparently rather unique undergraduate course.

In a typical module, while the earlier case-lets are manually solved, step-by-step, only the broad steps needed for the solution are provided for the later ones. During the semester, students are afforded the opportunity to solve many of both types of case-lets using Professor-provided highly structured Excel spreadsheets. They can access the Professor's own Adobe Excel solution, but not the formulae behind the correct solution. This approach is intended to (1) give students 
hands-on knowledge about how to use spreadsheets to solve marketing related problems described in the ten concept modules, and (2) reinforce their knowledge by going through the detailed computational process that involves first entering the case-let information in the Excel input cells, then figuring out the formulae for computing the answers in the Excel output cells. We would like to point out that the Excel templates that accompany many a marketing or other textbook have the formulae already in place. Therefore, the student has very little incentive and in our experience, very little clue about "how the correct answer was obtained" in these spreadsheet templates. In contrast, in the M and M Professor-provided spreadsheets, the students receive help in organizing and presenting the case-let data, but are forced to write their own formulae to come up with the correct answers. In addition, this format allows multiple levels of challenge, as desired by the Professor: students could be given the Excel solutions (in PDF format) and the formulae; solutions, but not the formulae (as implemented for the concept modules and assignments based on those); and neither the solution nor the formulae (as implemented for the "How To" modules and assignments based on those).

The "How To" modules are quite different from the concept modules. In the first "How To" (M-How to-01) students learn to develop a detailed Excel spreadsheet for a practice case-let on paper from scratch, as opposed to using the Professor's spreadsheet. They then solve their own spreadsheet and come up with the answers to the case-let. The second "How To" module (M-How to-02) requires students to create a Power Point presentation from their own just completed M-How to-01 Excel spreadsheet.

During the semester, student skills and knowledge base are assessed through 5 graded assignments, each worth $10 \%$ of the semester grade (accounting for $50 \%$ of the semester grade). Three of the graded assignments, typically one every month, involve solving 5 mini-case-lets 
each from the currently scheduled concept modules, using the Professor's Excel worksheets, as explained above. The fourth graded assignment, a comprehensive case called CC1, involves students creating their own Excel workbook for a brand new case-let, after completing M-How to-01 and practice case-lets therein. Here, the Professor does not provide the solution (Excel or PDF file), but simply provides the bottom line answer to the case-let as "clues" The fifth and last graded assignment, CC2, involves creating the Power point presentation for the $\mathrm{CC} 1$ case-let using the just completed Excel spreadsheet from M-How to-01, again after going through the practice case-lets in M-How to-02.

Exhibit 1 provides a description of the ten content modules and the two "How to" modules. Exhibit 2a illustrates a typical mini-case-let, while $2 \mathrm{~b}$ is its Excel template, in which the ?s in the Inputs section are to be replaced by raw data from the case-let and the Cs in the Outputs section are to be replaced by student-supplied formulae for obtaining the correct answers. Exhibit 2c is the Professor's PDF solution that is available to students, while Exhibit 2d is the Professor's formula sheet in PDF again, which is NOT provided to the students.

A mid term examination (20\%) and a final examination (30\%), both closed-book (formula sheet is provided) and multiple choice, account for the other half of the semester grade. The mid term exam consists of 25 questions to be completed in 80 minutes, while the final exam doubles the number of questions to 50 , but increases the time available to only 120 minutes. The exam questions are designed to test application rather than memory recall. Each question is a micro-case involving a marketing decision situation and the question typically asks students how they would approach the problem and provides 5 answer choices. The exam questions are mostly non-quantitative, emphasizing recognizing the correct approach to the situation, as opposed to number crunching. 


\section{Course Assessment:}

While the typical college-mandated student evaluation has been implemented, more specific feedback is obtained using an end of the semester questionnaire measuring students' perceived ease of use and self-efficacy (Davis 1989; Kraiger et al. 1993; Venkatesh and Davis 1996; Yi and Davis 2003). The perceived ease of use is measured through self reported difficulty associated with various assignments and concepts taught in the course, on a ten point semantic differential scale of 1 (Not at all difficult) to 10 (Very difficult). Perceived usefulness is also measured likewise on a scale of 1 (Very low) to 10 (Very high). Perceived outcome benefit is measured by asking students to assess their own competence on various outcome variables and its relevance to their future life and jobs using eight questions (A01, A02, and A04 through A09), again on a 1 (Strongly disagree) to 10 (Strongly agree) scale.

Because of the descriptive nature of this investigation, we primarily report descriptive statistics with some associative indicators such as correlations to get a feel for the relationships between various measures. Figure 1 presents a graph of descriptive statistics of the perceived usefulness and difficulty of various graded assignments. The chart indicates a congruent pattern between students' perceived usefulness and difficulty on various assignments with usefulness scores being slightly higher than the difficulty scores, except in the case-let of the bonus assignment and the Mid-term Exam. However, the correlations between them is low (highest $\mathrm{R}^{2}$ is 0.0324 for $\mathrm{CC} 1$ ). Figure 2 presents a graph of descriptive statistics of the perceived usefulness and difficulty of various concept and 'How to' modules. One again the pattern for perceived usefulness and difficulty seems to be congruent for all the modules but the correlations are very low (highest $\mathrm{R}^{2}$ is 0.0342 for M-How to- 01 ). Figure 3 presents a trend analysis of self reported 
scales (A01, A02, and A04 through A09) measuring competencies gained due to the $\mathrm{M}$ and $\mathrm{M}$ course across different terms (starting Spring 2004 through Spring 2006). All measures of self assessed competencies exhibit similar trends for their means and generally range between 6.5 and 8.25 on a $0-10$ scale. The Cronbach's Alpha score for these eight questions was 0.942 . In addition, except for A06 (After taking M\&M, I feel more confident about my preparation for job interviews) other measures of competence (A01, A02, A04, A05, A07, A08, and A09) were very tightly clustered. This may be because 'more confidence' could be resulting from improved selfconfidence concerning the use of the spreadsheet and may not be directly related to competence.

Finally, we checked for association using correlation coefficients between the composite score for competence (i.e., outcome benefit) as well as perceived difficulty, and usefulness, first for the assignments (Table 1) and then for the concept modules (Table 2.) We are not using multiple regression because prediction is not the objective of this study. We are also not interested in finding which of the assignments or concept modules influence the self assessed competence the most. We are merely interested in finding out whether the self-assessment of competence is associated with usefulness and difficulty. The figures in Table 1 and Table 2 suggest an association between the self assessed competence (strong and significant correlation coefficients) and the student's perceived usefulness of different assignments as well as various concept modules. In comparison, the relationship between competence and student's perceived difficulty of different assignments as well as various concept modules are almost non-existent (mostly non-significant). 


\section{Discussion:}

The Marketing and Money course has strong links to the behavioral model of learning (cf. Bandura 1986; Donovan and Radosevich 1999; Kozlowski et al. 2001; May and Kahnweiler 2000; and Salas and Cannon-Bowers 2001) - i.e., people learn by first watching someone else perform a target behavior and then reenacting it. Every concept taught in the $M$ and $M$ course is first demonstrated by the instructor. This is first observed and then re-enacted by the students. Afterwards, there is substantial reinforcement in the forms of various assignments. The case-lets used in the concept modules and assignments are designed to represent marketing decision making situations. This seems to enhance the students self efficacy despite the associated difficulty. In fact, our analyses indicate that as the perception of usefulness associated with various assignments increase, the student's self perception of competence or outcome benefits also increases. However, perceived difficulty seems to have little impact on competence

These findings are interesting for the future of spreadsheet and data-based decision making within the marketing context. In order for marketing to become a force in the board room, it needs to demonstrate greater accountability, especially financial and quantitative accountability (Baker and Holt 2004; Ambler 2003; Doyle 2000; and Simms 2003). Courses like $\mathrm{M}$ and $\mathrm{M}$, therefore, become crucial for inculcating such an orientation among future managers, i.e., our current students. Some of the students may indeed be a bit scared of anything quantitative and may find assignments and concepts that lean towards quantitative skills a bit too difficult. However, if the usefulness of such assignments and concepts are apparent, then students may be able to at least partially overcome their phobia, resulting in higher levels of competence or self -efficacy. The behavioral model of learning (Bandura 1986) offers some guidance as to how one could enhance learning (Yi and Davis 2003), especially when it involves 
using databases and spreadsheets to make marketing decisions. The process outlined in the $\mathrm{M}$ and $\mathrm{M}$ course could form a basis for successful future educational and training programs that inculcate an accountability mind set among marketing and other managers using a spreadsheet platform. This would be really valuable for the industry since the process used in the $\mathrm{M}$ and $\mathrm{M}$ course is theoretically rooted and seems to work. Our study also indicates that it is possible to inculcate an accountability mind set among marketing students and managers using the spreadsheet as a platform and the behavioral model of learning may be a way of making such training and education programs more effective. The findings suggest that the key is to make the assignments and concept modules relevant and useful, and not compromise on the rigor or the difficulty associated with them.

\section{Limitation and Implications:}

The main limitation is that this investigation is not based on an experiment. We did not investigate the effect of a controlled manipulation on student learning. We simply describe a course that relies on spreadsheet to impart a marketing accountability mindset and report the analysis of routinely collected student feedback data. The course content, its implementation and the feedback instrument have all continuously evolved since 1999 and were not custom created for this study. Self efficacy is captured by a single item measure of ease or difficulty of use [based on assertion by both Davis (1989) and Venkatesh and Davis (1996) that perceived ease of use is similar to self efficacy]. Therefore, what we have presented here are correlational findings rather than cause and effect relationships. We advocate using established multi-scale measure (e.g., Compeau, D. R. and C. A. Higgins 1995; Ramalingam et al. 2004 and 1998) in future research efforts. We did not measure the level of the students' marketing metric skills before the 
course and did not investigate the change in these as a result of taking M and M. It is also acknowledged that the ultimate benefit of any knowledge is accrued in the long term, what we call "post-training self efficacy" in the paper. We have very little idea of how M and M has benefited students in the long run, their careers etc, except via limited feedback from the handful of very positive anecdotal letters. We were somewhat constrained by the fact that the $\mathrm{M}$ and $\mathrm{M}$ course is part of the marketing program curriculum and hence does not lend itself easily to rigorous experimental manipulations and control. Hence it was not possible for us to associate the performance in exams and assignments with the assessment instrument. We also did not employ an external measure of competence or efficacy. However, despite these shortcomings, we believe that this investigation provides a description of a process-based training framework for imparting spreadsheet skills that would inculcate a marketing accountability mindset among marketing students. We also believe that the resultant descriptive statistics and the correlation analysis provide valuable insight into the effectiveness of the spreadsheet based course and an important finding: usefulness is a key determining factor of effectiveness.

We hope that this investigation forms the impetus for future, more detailed research efforts that investigate how to inculcate marketing accountability using spreadsheet and data based analysis platforms. There is a need to incorporate some of the well known learning models and theories to develop a contingency perspective of imparting spreadsheet-based skills. It is imperative that we continue to investigate this phenomenon and expand our knowledge base on how to improve such training and education programs. Otherwise, we would continue to waste a significant portion of the billions of dollars spent on computer based training (Yi and Davis 2003) as well as risk an opportunity lost due to marketing not making its full contribution due to a lack of accountability mindset (Baker and Holt 2004). 


\section{Reference}

Ajzen, I. and M. Fishbein (1980), Understanding Attitudes and Predicting Social Behavior, Englewood Cliff, NJ: Prentice Hall.

Ambler, T. (2000a), “Marketing Metrics,” Business Strategy Review, 11 (2), 59-66.

Ambler, T. (2000b), Marketing and the Bottom Line: The New Metrics of Corporate Wealth, Financial times/Prentice Hall, London.

Ambler, T. (2003), “Are you a Wimp or a Warrior?” Marketing, 23 October, 22-23.

Bagozzi, Richard P. and Pratibha A. Dabholkar (2000), "Discursive Psychology: An Alternative Conceptual Foundation to Means-End Chain Theory," Psychology and Marketing, 17 (7), 535-586.

Baker, Susan, and Sue Holt (2004), "Making Marketers Accountable: A Failure of Marketing Education?" Marketing Intelligence and Planning, 22 (5), 557-567.

Bandura, A. (1986), Social Foundations of Thought and Action: A Social Cognition Theory, PrenticeHall, Englewood Cliffs, NJ.

Black, Iain R., Alejandra Efron, Christina Ioannou, and John M. Rose (2005), "Designing and Implementing Internet Questionnaires Using Microsoft Excel," Australian Marketing Journal, 13 (2), 6172.

Bolt, M. A., L. N. Killough, H. C. Koh (2001), "Testing the Interaction Effects of Task Complexity in Computer Training using the Social Cognitive Model," Decision Science, 32, 1-20.

Colquitt, J. A., J. A. LePine, R. A. Noe (2000), "Toward an Integrative Theory of Training Motivation: A Meta-Analytic Path Analysis of 20 Years of research," Journal of Applied Psychology, 85, 678-707.

Compeau, D. R. and C. A. Higgins (1995), “Application of Social Cognitive Theory to Training for Computer Skills,” Information System Research, 6, 118-143.

Davis, F. D. (1989), "Perceived Usefulness, Perceived Ease of Use, and User Acceptance of Information Technology," MIS Quarterly, 13, 319-340.

Davis, F. D. (1993), "User Acceptance of Information technology: System Characteristics, User Perceptions and Behavioral Impacts," International Journal of Man-Machine Studies, 38, 475-487.

Davis, F. D., R. P. Bagozzi, and P.R. Warshaw (1989), “User Acceptance of Computer technology: A Comparison of two Theoretical Models," Management Science, 35, 982-1003.

Dembeck, Jennifer L. and David E. Stout (1997), "Using a Spreadsheet to Solve a Multinational Marketing Problem," Management Accounting, 78 (7), 33-39.

Devlin, Derek, Grete Birtwistle, and Norma Macedo (2003), "Food Retail Positioning Strategy: A MeansEnd Chain Analysis," British Food Journal, 105 (9), 653-670. 
Donovan, J. J. and D. J. Radosevich (1999), “A Meta-Analytic Review of the Distribution of Practice Effect: Now you See It, Now you Don't,” Journal of Applied Psychology, 84, 795-805.

Doyle, P. (2000), “Valuing Marketing's Contribution,” European Management Journal, 18 (3), 233-245.

Fishbein, M. and I. Ajzen, (1975), Belief, Attitude, Intention and Behavior: An Introduction to Theory and Research, Reading, MA: Addison-Wesley.

Gist, M. E., B Rosen, and C. Schwoerer (1988), "The Influence of Training Methods and Trainee Age on the Acquisition of Computer Skills," Personnel Psychology, 41, 255-265.

Gist, M. E., C. Schwoerer, and B Rosen, (1989), "Effects of Alternative Training Methods on SelfEfficacy and Performance in Computer Software Training," Journal of Applied Psychology, 74, 884-891.

Graham, R. C and K. D. Frankenburger (2000), "The Contribution of Changes in Advertising Expenditure to Earnings and Market Values," Journal of Business Research, 50 (2), 149-156.

Grossman, Thomas A. (2006), "Integrating Spreadsheet Engineering in a Management Science Course: A Hierarchical Approach," INFORMS: Transactions on Education, 7 (1), 1-30.

Gutman, Jonathan (1982), "A Means-End Chain Model Based on Consumer Categorization Processes," Journal of Marketing, 46, 60-72.

Gutman, Jonathan (1997), "Means-End Chains as Goal Hierarchies," Psychology and Marketing, 14 (6), 545-560.

Gutman, Jonathan and George Miaoulis (2003), "Communicating a Quality Position in Service Delivery: An Application in Higher Education,” Managing Service Quality, 13 (2), 105-111.

Hwarng, H. Brian (2001), “A Modern Simulation Course for Business Students,” Interface, 31 (3), 66-75.

Johnson, R. D. and G. M. Marakas (2000), "The Role of Behavior Modeling in Computer Skill Acquisition - Toward Refinement of the Model," Information System Research, 11, 402-417.

Jordan, E., L. Lasdon, M. Lenard, J. Moore, S. Powell, and T. Willemain, (1997), “OR/MS and MBAs," OR/MS Today, 24 (1), 36-41.

Kozlowski, S. W. J, S. M. Gully, K. G. Brown, E. Salas, E. M. Smith, E. R. Nason (2001), "Effects of Training Goals and Goal Orientation on Multidimensional Training Outcomes and performance Adaptability," Organization Behavior Human Decision Process, 85, 1-31.

Kraiger, K., J. K. Ford, and E. Salas (1993), "Application of Cognitive, skill-based, and Affective Theories of Learning Outcomes to New Methods of Training Evaluation," Journal of Applied Psychology, 78, 311-328.

Kumar, V., S. N. Ramaswami, R. K. Srivastava (2000), “A Model to Explain Shareholder Returns: Marketing Implications,” Journal of Business Research, 50 (2), 157-168.

Locke, E. A. and G. P. Latham (1990), A Theory of Goal Setting and Task Performance, Prentice-Hall, Englewood Cliffs, NJ. 
Lilien, Gary L., Arvind Rangaswamy, and Timothy Matanovich (1998), "The Age of Marketing Engineering," Marketing Management, 7 (1), 48-50.

Markham, Ina S. and Susan W. Palocksay. (2006), "Scenario Analysis in Spreadsheets with Excel's Scenarion Tool,” INFORMS: Transactions on Education, 6 (2), 1-12.

May, G. L. and W. M. Kahnweiler (2000), "The Effect of Mastery Practice Design on Learning and Transfer in Behavior Modeling Training," Personnel Psychology, 53, 353-373.

McDonald, M., R. Shaw, and C. White (2000), “Light into Marketing's Black Hole,” Marketing Business.

McDonald, M. (2006), "Let us Drop, Once and for all, the Nonsense about Marketing Return on Investment," Journal of Medical Marketing, 5 (3), 256-280.

Moorman, Christine and Ronald Rust (1999), "The Role of Marketing," Journal of Marketing, 63 (Special Issue), 180-197.

Palocksay, Susan W. and Ina S. Markham (2002), Teaching Spreadsheet-Based Decision Support Systems with Visual Basic for Applications," Information Technology, Learning, and Performance Journal, 20 (1), 27-35.

Papageorgiou, J. C. (1996), “Are we Promoting OR/MS to Our Future Clients?” International Journal of Operations and Quantitative Management, 2 (3), 231-238.

Pieters, Rik, Günther Bottschen and Eva Thelen (1998), "Customer Desire Expectations about Service Employees: An Analysis of Hierarchical Relations," Psychology and Marketing, 15 (8), 755-773.

Ramalingam V. and Wiedenbeck S. (1998), "Development and validation of scores on a computer programming self-efficacy scale and group analyses of novice programmer self-efficacy," Journal of Educational Computing Research, 19 (4), 365--379.

Ramalingam, V., D. Labelle, and Wiedenbeck S. (2004), "Self Efficacy and Mental Models in Learning to Program," Proceedings of the 9th annual SIGCSE conference on Innovation and technology in computer science education, June 28-30, 171-175.

Salas, E. and J. A. Cannon-Bowers (2001), “The Science of Training: A Decade of progress,” Annual Review of Psychology, 52, 471-499.

Shaw, R. and L. Mazur (1997), "Marketing Accountability: Improving Business Performance," FT Management Report, FT Retail and Consumer Publishing, London.

Seth, J. N., and R. S. Sisodia (2002), Marketing Productivity, Issues and Analysis," Journal of Business Research, 55, 349-362.

Simms, J. (2003), "How to Drive Business Success... and Your Own career," Marketing, 18 September, $22-23$.

Simon, S., V. Grover, J. Teng, K. Whitecomb (1996), "The relationship of Information System Training Methods and Cognitive Ability to End-User Satisfaction, Comprehension, and Skill Transfer: A Longitudinal Field Study," Information System Research, 7, 466-490. 
Simon, S. and J. Werner (1996), "Computer Training Through Behavior Modeling, Self-Paced and Instructional approach: A Field Experiment," Journal of Applied Psychology, 81, 648-659.

Sosin, Kim, Betty J. Blecha, Rajshree Agarwal, Robin L. Bartlett, and Joseph I. Daniel (2004), "Efficiency in the Use of Technology in Economic Education: Some Preliminary Results," The American Economics Review, 94 (2), 253-258.

Stajkovic, A. D. and F. Luthans (1998), "Self-Efficacy and Work-Related Performance: A Meta Analysis," Psychological Bulletin, 124, 240-261.

Thomas, Michael J. (2000), "Marketing Performance Measurement: Directions for Development," Journal of Targeting, Measurement and Analysis for marketing, 9 (1), 70-91.

Venkatesh, Viswanath and Fred D. Davis (1996), "A Model of the Antecedents of Perceived Ease of Use: Development and Test," Decision Science, 27 (3), 451-481.

Yi, Mun Y., and Fred D. Davis (2003), "Developing and Validating an Observational Learning Model of Computer Software Training and Skill Acquisition," Information Systems Research, 14 (2), 146-169.

Zinkhan, G. M. and J. A. Verbrugge (2000a), "Introduction to the Special Issue on the Marketing/Finance Interface," Journal of Business Research, 50 (2), 139-142.

Zinkhan, G. M. and J. A. Verbrugge (2000b), "The Marketing and Finance Interface: Two Divergent and Complimentary Views of the Firm," Journal of Business Research, 50 (2), 143-148. 
Figure 1

Perceived Usefulness and the Difficulty of Various Graded Assignments

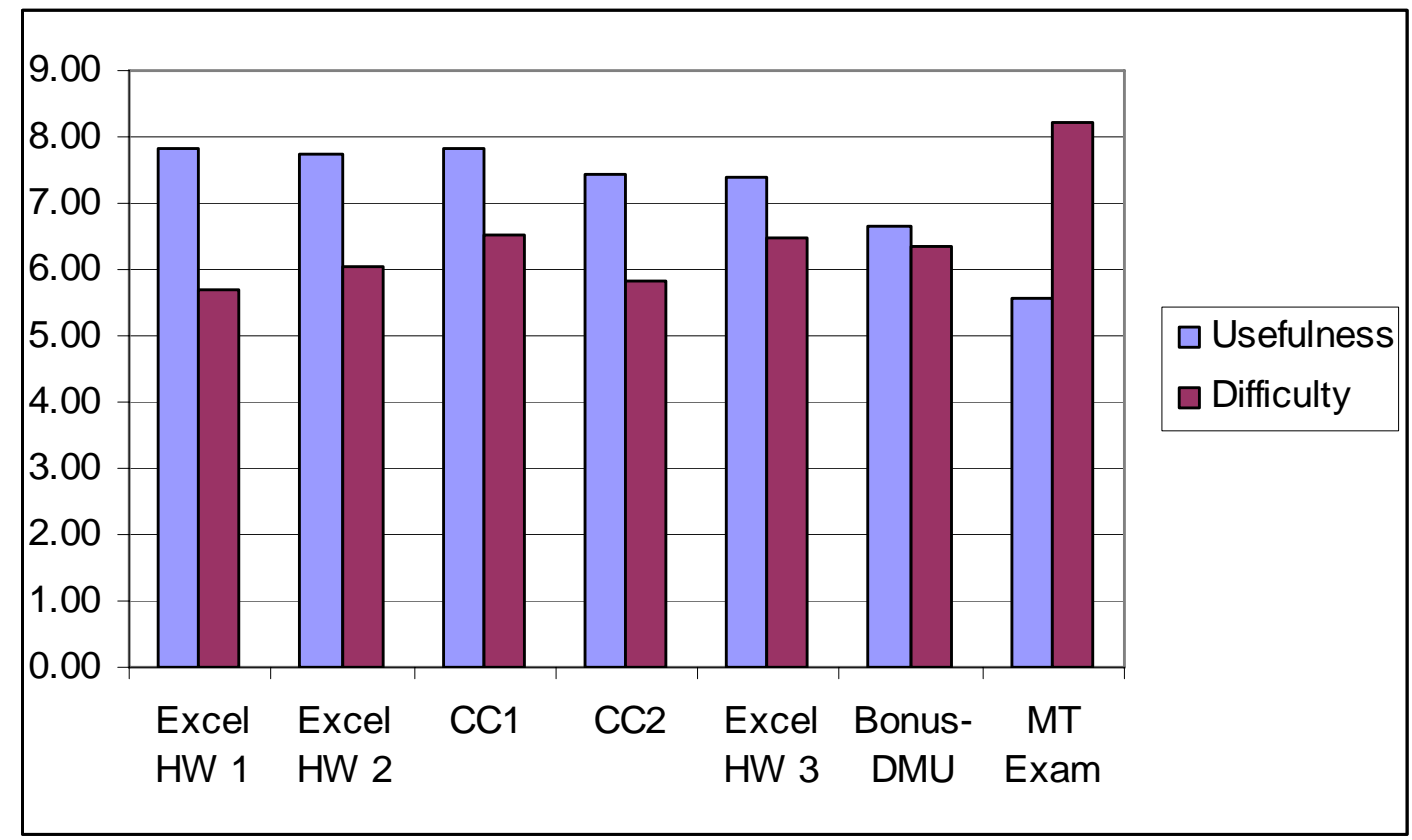

Figure 2

Perceived Usefulness and Difficulty of Content Modules

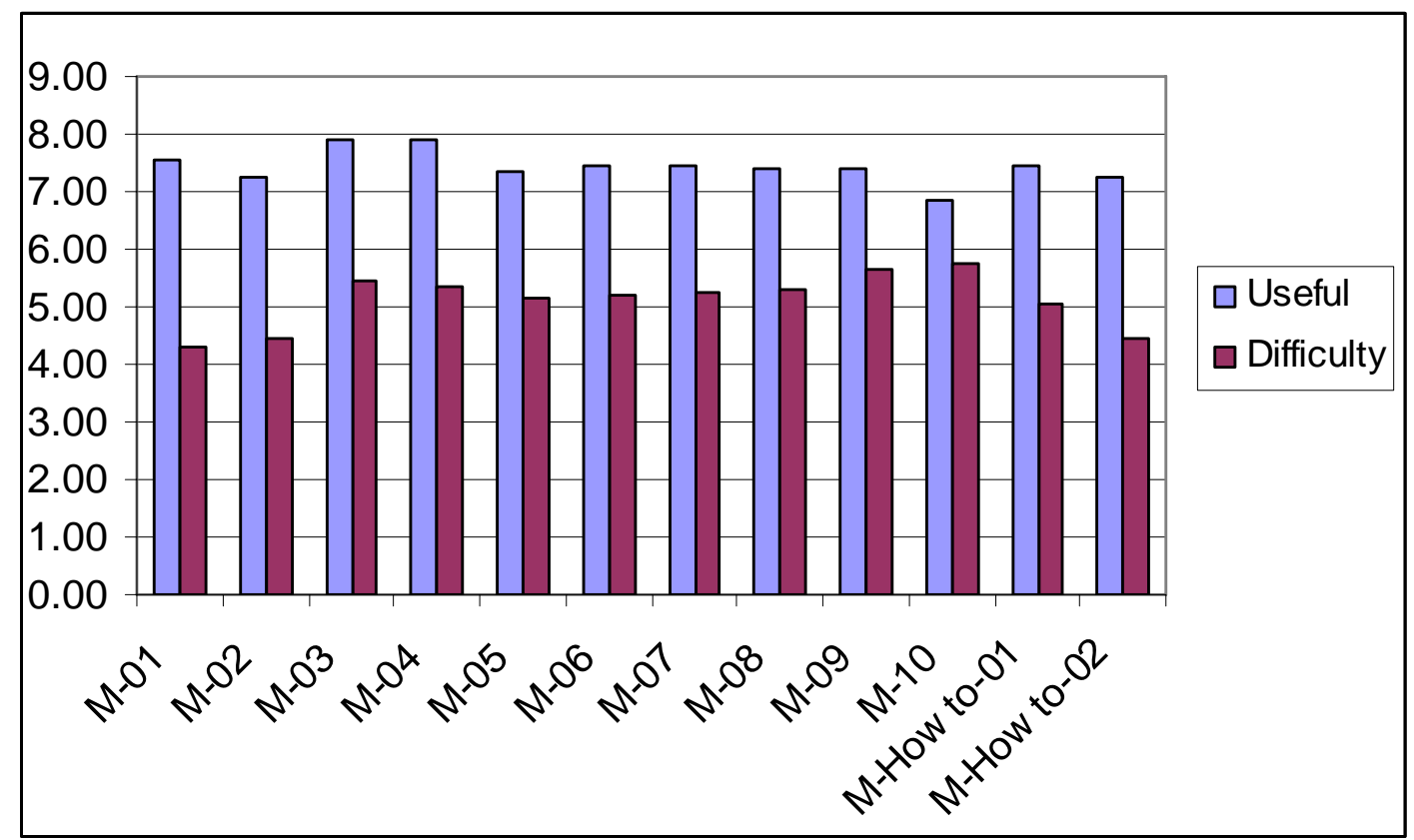

Measurement Items:

1. Please rate the USEFULNESS (in terms of its learning value) of EACH Graded Assignment or Topic Module on a 1 (very low) to a 10 (very high) scale.

2. Please rate the DIFFICULTY (in terms of understanding and doing it) of EACH Graded Assignment or Topic Module on a 1 (very low) to a 10 (very high) scale. 
Figure 3

Trends in Self Reported Competence Scores

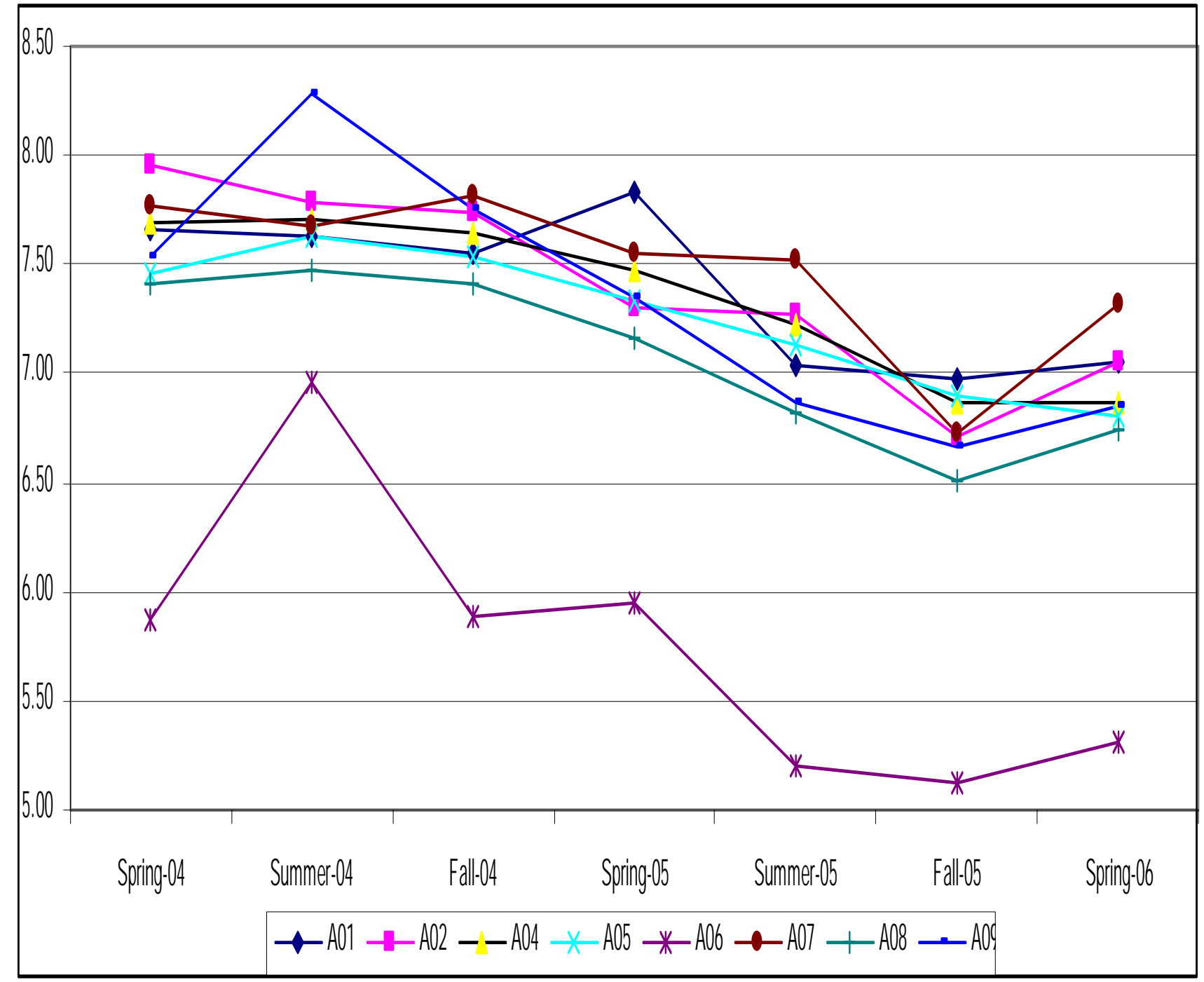

Measurement scale Items for assessing outcome benefits or competence:

A01 M\&M taught me various tools useful for Marketing decision making $(\beta=-0.118)$.

A02 M\&M improved my ability to approach an analytical problem methodically, step by step $(\beta=-0.180)$.

A04 After taking M\&M, I feel more confident about using basic math and arithmetic in a Marketing decision making context $(\beta=-0.147)$.

A05 After taking M\&M, I feel more confident about "working the case numbers" in future classes $(\beta=-0.128)$.

A06 After taking M\&M, I feel more confident about my preparation for job interviews $(\beta=-0.139)$.

A07 After taking M\&M, I feel more confident about using spreadsheets in my job, career etc. $(\beta=-0.128)$.

A08 After taking M\&M, I feel more confident about using presentation software in my job, career etc. $(\beta=-0.140)$.

A09 I expect that the skills I learned in M\&M would be useful in my future life, in general, as well $(\beta=-0.174)$.

- Cronbach's Alpha score for these eight item scale was 0.942 for the entire data set (low of 0.908 and a high of 0.961).

- $\quad$ Responses to these course assessment questions were measured on a semantic differential scale anchored between 1 (Strongly Disagree) and 10 (Strongly Agree). 
Table 1

Correlations between Self Reported Competence Scores and Usefulness and Difficulty Associated with Various Assignments

\begin{tabular}{|c|c|c|c|c|c|c|c|c|c|}
\hline & $\mathrm{R}$ & Mean & SD & $\mathrm{N}$ & & $\mathrm{R}$ & Mean & SD & $\mathrm{N}$ \\
\hline q13 "Usefulness: Excel HW 2" & 0.55 & 7.75 & 1.95 & 611 & Q14h "Difficulty: Excel HW 2" & 0.12 & 6.04 & 2.05 & 214 \\
\hline q12 "Usefulness: CC2" & 0.43 & 7.43 & 2.26 & 609 & Q14g "Difficulty: CC2" & 0.04 & 5.83 & 2.56 & 213 \\
\hline Q13a Usefulness: Excel HW 3 & 0.54 & 7.38 & 2.17 & 115 & q14h1 "Difficulty: Excel HW 3" & 0.14 & 6.46 & 2.11 & 114 \\
\hline q14 "Usefulness: Module 12 (Bonus): DMU" & 0.40 & 6.66 & 2.59 & 403 & Q14i "Difficulty: Module 12 (Bonus): DMU" & 0.08 & 6.34 & 2.41 & 137 \\
\hline
\end{tabular}

Correlation Coefficient figures in bold are not significant at $\mathrm{p}<0.0$.

Table 2

Correlations between Self Reported Competence Scores and Usefulness and Difficulty Associated with 12 Course Content Modules

\begin{tabular}{|c|c|c|c|c|c|c|c|c|c|}
\hline Variables & $\mathrm{R}$ & Mean & SD & $\mathrm{N}$ & Variables & $\mathrm{R}$ & Mean & SD & $\mathrm{N}$ \\
\hline competence & 1.00 & 7.12 & 1.93 & 624 & competence & 1.00 & 7.12 & 1.93 & 624 \\
\hline q25 "Usefulness: Module 01" & 0.47 & 7.55 & 2.07 & 616 & q39 "Difficulty: Module 01" & 0.00 & 4.31 & 2.42 & 617 \\
\hline q26 "Usefulness: Module 02" & 0.48 & 7.26 & 2.15 & 590 & q40 "Difficulty: Module 02" & -0.02 & 4.44 & 2.31 & 594 \\
\hline q27 "Usefulness: Module 03" & 0.57 & 7.90 & 2.05 & 615 & q41 "Difficulty: Module 03" & 0.03 & 5.47 & 2.29 & 618 \\
\hline q28 "Usefulness: Module 04" & 0.58 & 7.88 & 1.93 & 615 & q42 "Difficulty: Module 04" & -0.01 & 5.34 & 2.26 & 617 \\
\hline q31 "Usefulness: Module 05" & 0.54 & 7.36 & 1.96 & 614 & q45 "Difficulty: Module 05" & 0.03 & 5.15 & 2.14 & 612 \\
\hline q32 "Usefulness: Module 06" & 0.56 & 7.44 & 1.91 & 614 & q46 "Difficulty: Module 06" & 0.03 & 5.20 & 2.11 & 612 \\
\hline q33 "Usefulness: Module 07" & 0.56 & 7.44 & 1.95 & 613 & q47 "Difficulty: Module 07" & 0.01 & 5.27 & 2.17 & 610 \\
\hline q34 "Usefulness: Module 08" & 0.56 & 7.42 & 1.96 & 615 & q48 "Difficulty: Module 08" & 0.02 & 5.32 & 2.18 & 610 \\
\hline q35 "Usefulness: Module 09" & 0.54 & 7.40 & 2.10 & 611 & q49 "Difficulty: Module 09" & -0.01 & 5.65 & 2.24 & 607 \\
\hline q36 "Usefulness: Module 10" & 0.47 & 6.87 & 2.32 & 474 & q50 "Difficulty: Module 10" & 0.03 & 5.77 & 2.39 & 481 \\
\hline q29 "Usefulness: Module-How & 0.53 & 7.45 & 2.26 & 613 & q43 "Difficulty: Module-How tc & 0.08 & 5.04 & 2.52 & 615 \\
\hline q30 "Usefulness: Module-How to-02" & 0.45 & 7.23 & 2.36 & 614 & q44 "Difficulty: Module-How to-02" & 0.08 & 4.44 & 2.52 & 613 \\
\hline
\end{tabular}

Correlation Coefficient figures in bold are not significant at $p<0.0$. 


\section{Exhibit 1: A Detailed Description of the 12 Modules}

\begin{tabular}{|c|c|c|c|}
\hline Module \# & Module Name and Objective & Detailed Description/Topics Covered & List of Cases \\
\hline $\begin{array}{l}\text { M01 } \\
74 \text { slides }\end{array}$ & $\begin{array}{l}\text { Percentages and } \\
\text { Weighted Average } \\
\text { Objective: Quick remedial to } \\
\text { improve understanding }\end{array}$ & $\begin{array}{l}\text { Remedial work to improve interpretation of } \\
\text { percentages; Calculation and application of simple } \\
\text { trend; Correct understanding of how to calculate a } \\
\text { Weighted Average }\end{array}$ & $\begin{array}{l}\text { Fit-It Corporation; Positron Inc } \\
\text { Tota Inc; } \\
\text { Swaaguth Inc } \\
\text { Professor Stingy } \\
\text { Two of these become part of Excel } \\
\text { Homework } 1 \text { ( } 5 \text { cases) }\end{array}$ \\
\hline $\begin{array}{l}\text { M02 } \\
61 \text { slides }\end{array}$ & $\begin{array}{l}\text { Balance Sheet and } \\
\text { Income Statement } \\
\text { Objective: Basic understanding } \\
\text { of Balance Sheet and Income } \\
\text { Statement and their relevance to } \\
\text { Marketing }\end{array}$ & $\begin{array}{l}\text { Basics of Balance Sheet and Income Statement; } \\
\text { Calculating Cost of Goods Sold for channel } \\
\text { intermediaries and manufacturers, pro-forma income } \\
\text { statement, Calculating and using index numbers and } \\
\text { ratios from a balance sheet, income statement and both }\end{array}$ & $\begin{array}{l}\text { Consumer Products Company } \\
\text { Bountiful Bakery Company } \\
\text { Aaron Enterprises Inc; } \\
\text { Stoneham Auto Supplies } \\
\text { Lone Star Manufacturing Co } \\
\text { Clear Voice Inc } \\
\text { Three of these become part of Excel } \\
\text { Homework } 1 \text { (5 cases) }\end{array}$ \\
\hline $\begin{array}{l}\text { M03 } \\
60 \text { slides }\end{array}$ & $\begin{array}{l}\text { Channel Markups } \\
\text { Objective: Correct interpretation } \\
\text { of markup information in } \\
\text { calculating channel prices }\end{array}$ & $\begin{array}{l}\text { Channel Markups, } \\
\text { Markup in a multi-level channel, Expressing, applying } \\
\text { and converting markup information, markup chain, } \\
\text { markdowns } \\
\text { Using markup in pricing a product }\end{array}$ & $\begin{array}{l}\text { Lone Star Lamp Company; Krispy Kreme } \\
\text { Company } \\
\text { Western Boot Company \#1; \#2; and \#3 } \\
\text { Baby Magic Inc } \\
\text { Two of these become part of Excel } \\
\text { Homework } 2 \text { (5 cases) }\end{array}$ \\
\hline $\begin{array}{l}\text { M04 } \\
96 \text { slides }\end{array}$ & $\begin{array}{l}\text { Contribution Analysis } \\
\text { and the Breakeven point } \\
\text { Objective: Comprehensive } \\
\text { understanding of the breakeven } \\
\text { point in marketing contexts }\end{array}$ & $\begin{array}{l}\text { Variable Costs, Fixed Costs, Sunk costs, } \\
\text { \$ Contribution and \% Contribution, } \\
\text { Alternative ways of calculating breakeven units and } \\
\text { dollars, Profitability and breakeven point, Different } \\
\text { ways of handling profit objective in breakeven } \\
\text { analysis: \$ profit, \% profit/sales, \%ROI, \% increase in } \\
\text { last year's \$ profit, calculating breakeven market share } \\
\% \text { in units and dollars, incremental breakeven } \\
\text { analysis, charting breakeven analysis, relationship } \\
\text { between contribution analysis and the income } \\
\text { statement }\end{array}$ & $\begin{array}{l}\text { Widgets Inc } \\
\text { Bountiful Bakery } \\
\text { Metro Manufacturing Co } \\
\text { Texas Bearing Company } \\
\text { Remington Groomers } \\
\text { Galaxy Music } \\
\text { Athens Nurseries } \\
\text { Three of these become part of Excel } \\
\text { Homework } 2 \text { (5 cases) }\end{array}$ \\
\hline
\end{tabular}




\section{Exhibit 1: A Detailed Description of the 12 Modules (Continue..)}

\begin{tabular}{|c|c|c|c|}
\hline Module \# & Module Name and Objective & Detailed Description/Topics Covered & List of Cases \\
\hline \multirow[t]{2}{*}{$\begin{array}{l}\text { M05M06 } \\
65 \text { slides }\end{array}$} & $\begin{array}{l}\text { M05: Product } \\
\text { Objective: Learn analyses } \\
\text { typically encountered and } \\
\text { necessary in introducing a new } \\
\text { product }\end{array}$ & $\begin{array}{l}\text { Breakeven, incremental breakeven, profitability } \\
\text { Analysis and scenario analysis for alternative } \\
\text { assumptions for a new product, Cannibalization } \\
\text { analysis }\end{array}$ & $\begin{array}{l}\text { Alamo Manufacturing Co } \\
\text { Apfel's I-Tunes; Wipra Inc } \\
\text { Great Lakes Inc } \\
\text { Hannibal Inc.; Turfex Inc } \\
\text { One of these becomes part of Excel } \\
\text { Homework } 3\end{array}$ \\
\hline & $\begin{array}{l}\text { M06: Promotion } \\
\text { Objective: Learn analyses } \\
\text { typically encountered in } \\
\text { promoting a product }\end{array}$ & $\begin{array}{l}\text { Breakeven, incremental breakeven and profitability } \\
\text { analysis in the context of promotional choices, } \\
\text { Cannibalization in promotion }\end{array}$ & $\begin{array}{l}\text { Texas Diversified Electronics; Pegasus Inc; } \\
\text { Texas Grills Inc; } \\
\text { Major League Baseball India; BFV-10 } \\
\text { Valves; } \\
\text { Finn Fones Inc; Baja Foods inc; Gulf States } \\
\text { Petroleum Co; } \\
\text { La Siesta Inns } \\
\text { One of these becomes part of Excel } \\
\text { Homework } 3 \text { (5 cases) }\end{array}$ \\
\hline \multirow[t]{2}{*}{$\begin{array}{l}\text { M07M08 } \\
60 \text { slides }\end{array}$} & $\begin{array}{l}\text { M07: Price } \\
\text { Objective: Learn analyses } \\
\text { typically encountered and } \\
\text { necessary in pricing a product }\end{array}$ & $\begin{array}{l}\text { Pricing a product, Markup pricing, Target pricing, } \\
\text { perceived value pricing } \\
\text { Elasticity of demand }\end{array}$ & $\begin{array}{l}\text { Lone Star lamp Co; Printo Printers } \\
\text { John and Jim Bagel Shop } \\
\text { Shaaka For Life } \\
\text { One of these becomes part of Excel } \\
\text { Homework } 3 \text { (5 cases) }\end{array}$ \\
\hline & $\begin{array}{l}\text { M08: Place } \\
\text { Objective: Learn analyses } \\
\text { typically encountered and } \\
\text { necessary in planning a channel } \\
\text { of distribution or changing an } \\
\text { existing channel of distribution }\end{array}$ & $\begin{array}{l}\text { Placing products: choosing among alternative new } \\
\text { channels of distribution by calculating and comparing } \\
\text { the distribution costs of each and/or by comparing } \\
\text { these to present costs. }\end{array}$ & $\begin{array}{l}\text { Palatial Tiles Inc } \\
\text { This becomes part of Excel Homework } 3 \text { ( } 5 \\
\text { cases) }\end{array}$ \\
\hline $\begin{array}{l}\text { M09 } \\
62 \text { slides }\end{array}$ & $\begin{array}{l}\text { Net Present Value } \\
\text { Objective: Basic understanding } \\
\text { of the NPV concept in } \\
\text { marketing contexts }\end{array}$ & $\begin{array}{l}\text { Simple Interest vs. Compound Interest, Present and } \\
\text { Future Value, Net Present Value, Cost of Capital, } \\
\text { Payback Period, IRR }\end{array}$ & $\begin{array}{l}\text { Project A vs. Project B } \\
\text { Project X vs. Project Y } \\
\text { Project M vs. Project N } \\
\text { Widgets Inc; GGK Corporation } \\
\text { One of these becomes part of Excel } \\
\text { Homework } 3 \text { (5 cases) }\end{array}$ \\
\hline
\end{tabular}




\section{Exhibit 1: A Detailed Description of the 12 Modules (Continue..)}

\begin{tabular}{|l|l|l|l|}
\hline Module \# & Module Name and Objective & Detailed Description/Topics Covered & List of Cases \\
\hline $\begin{array}{l}\text { M10 slides } \\
\text { Decision Making under } \\
\text { Uncertainty }\end{array}$ & $\begin{array}{l}\text { The Environment of Decision Making, Alternatives vs. } \\
\text { Uncertainties, Decision Trees and Probability Tables, } \\
\text { Objective: Basic understanding } \\
\text { of how to handle uncertainty in } \\
\text { marketing contexts }\end{array}$ & $\begin{array}{l}\text { Imfifying Decision Trees, value of Perfect } \\
\text { Information, Value of Imperfect Information }\end{array}$ & $\begin{array}{l}\text { This module was optional and the TBI case } \\
\text { could be completed for bonus points }\end{array}$ \\
\hline $\begin{array}{l}\text { M-How to- } \\
54 \text { slides }\end{array}$ & $\begin{array}{l}\text { Designing an Excel } \\
\text { Workbook } \\
\text { Objective: Prepare a workbook } \\
\text { from scratch for a case on paper }\end{array}$ & $\begin{array}{l}\text { Design the Inputs section, Outputs section, then solve } \\
\text { the workbook, format the cells, format for printing, and } \\
\text { print the numeric as well as formula worksheets to look } \\
\text { completed worksheets to Adobe PDF. }\end{array}$ & $\begin{array}{l}\text { South Texas Seafood Company } \\
\text { Gulf Coast Publishing Company } \\
\text { plus Graded Assignment: Comprehensive } \\
\text { Case 1 }\end{array}$ \\
\hline $\begin{array}{l}\text { M-How to- } \\
\text { c2 } \\
55 \text { slides }\end{array}$ & $\begin{array}{l}\text { Designing a PowerPoint } \\
\text { presentation } \\
\text { Objective: Prepare a } \\
\text { presentation from scratch for a } \\
\text { case that has been already } \\
\text { solved using Excel }\end{array}$ & $\begin{array}{l}\text { Create the basic chart shapes in the completed CC1.xls, } \\
\text { import them into PowerPoint, add all bells and whistles, } \\
\text { print handouts of the slides without and with the fancy } \\
\text { background. Also, learn how to print the completed } \\
\text { presentation to Adobe PDF. }\end{array}$ & $\begin{array}{l}\text { South Texas Seafood Company } \\
\text { Gulf Coast Publishing Company } \\
\text { plus Graded Assignment: Comprehensive } \\
\text { Case 2 }\end{array}$ \\
\hline
\end{tabular}


Exhibit 2a: A Typical Case-let

TEXAS BEARING COMPANY

(this is available to students)

This case-let is a somewhat modified version of original course materials developed and kindly permitted for use in this class by Prof. Sam Gillespi.

Texas Bearing Company (TBC) is a small manufacturer of precision machine bearings. Typical of the many different sizes that TBC manufactures is the 3 inch carbon steel cone bearing. TBC sells this to wholesale industrial distributors for resale to retailers of replacement parts. The retailers finally sell the bearing to industrial end-user customers, typically at a retail price of $\$ 32.00$. TBC estimates that the labor and materials used to make a bearing runs about $\$ 9.48$. Additionally, $\$ 13,650$ is required to setup the production run, regardless of the number of bearings produced.

TBC's marketing program is fairly lean: two fields sales representatives who call on the industrial distributors referred to above. Each salesperson receives a salary of $\$ 36,000$ and travel support of $\$ 9,000$. Each sales representative also receives a $5 \%$ commission for every bearing sales to a distributor account. TBC's advertising and sales promotion efforts total $\$ 6,000$. Retailers average about $40 \%$ markup based on their selling price to industrial customers, while the industrial distributor's markup $33 \%$ on the price paid to TBC for the bearings. Finally, TBC expects a minimum contribution to margin (i.e. CTM or profits) of $\$ 37,000$ from its operations.

Questions:

1. What is the selling price of a bearing at each stage in the channel? That is selling price of the retailer, the wholesaler, the manufacturer (TBC).

2. Calculate, if necessary, then itemize, total and show TBC's variable costs per bearing.

3. Calculate TBC's $\$ C$ (i.e., UVCM) and \%C (i.e. PVCM) per bearing.

4. Itemize and then total TBC's Total Direct Fixed Costs, without the profit objective.

5. What is TBC's Breakeven (RLS) point in units and dollars, without the profit objective?

6. What is TBC's Total Direct Fixed Costs, with the profit objective?

7. What is TBC's Breakeven (RLS) point in units and dollars, with the profit objective? 
Exhibit 2b: Excel Template for a Typical Case-let (this is available to students)

\begin{tabular}{|c|c|c|c|c|c|c|c|}
\hline & $\mathrm{A}$ & $\mathrm{B}$ & $\mathrm{C}$ & $\mathrm{D}$ & $E$ & $\mathrm{~F}$ & G \\
\hline 1 & \multicolumn{7}{|c|}{ Texas Bearing Company } \\
\hline 2 & \multicolumn{7}{|c|}{ IIlustration of breakeven analysis without and with profit } \\
\hline 3 & \multicolumn{7}{|c|}{ worksheet created by: Dr. Gopala Ganesh, UNT, Denton, Texas } \\
\hline 4 & & & & & & & \\
\hline 5 & \multicolumn{7}{|c|}{ INPUTS SECTION } \\
\hline 6 & & & & & & & \\
\hline 7 & \multicolumn{7}{|c|}{ Information on Prices and Margins: } \\
\hline 8 & & & & & & & \\
\hline 9 & \multicolumn{3}{|c|}{ Retail Price of a typical TBC Bearing } & & & & $?$ \\
\hline 10 & \multicolumn{4}{|c|}{ Average retailer $\%$ markup on selling price } & & & $?$ \\
\hline 11 & \multicolumn{4}{|c|}{ Wholesale \% distributor markup on cost } & & & ? \\
\hline 12 & & & & & & & \\
\hline 13 & \multicolumn{3}{|c|}{ Information on Variable Costs: } & & & & \\
\hline 14 & & & & & & & \\
\hline 15 & \multicolumn{4}{|c|}{ Labor and Material Cost of Each Bearing } & & & $?$ \\
\hline 16 & \multicolumn{3}{|c|}{ Sales Representative Commission $\%$} & & & & $?$ \\
\hline 17 & & & & & & & \\
\hline 18 & Informat & on Fixed C & & & & & \\
\hline 19 & & & & & & & \\
\hline 20 & Producti & Setup & & & & & ? \\
\hline 21 & Salesper & Salary & & & & & $?$ \\
\hline 22 & Salesper & Travel Su & & & & & $?$ \\
\hline 23 & Cost of $A$ & ertising and & es Promotio & & & & ? \\
\hline 24 & & & & & & & \\
\hline 25 & Informat & Profit Goo & & & & & \\
\hline 26 & & & & & & & \\
\hline 27 & Expectec & ontribution & argin & & & & $?$ \\
\hline 28 & & & & & & & \\
\hline 29 & Informat & Other & & & & & \\
\hline 30 & & & & & & & \\
\hline 31 & Number & ield Sales & esentatives & & & & $?$ \\
\hline 32 & & & & & & & \\
\hline 33 & OUTPUר & SECTION & & & & & \\
\hline 34 & & & & & & & \\
\hline 35 & Q1 & & & & & & \\
\hline 36 & Retailer's & lling price & earing & & & & c \\
\hline 37 & Retailer's & st price pe & & & & & $\mathrm{c}$ \\
\hline 38 & Wholesa & selling pric & bearing & & & & c \\
\hline 39 & Wholesa & Cost & & & & & $\mathrm{c}$ \\
\hline 40 & Hence, $T$ & (manufact & selling price & er bearing & & & $\mathrm{c}$ \\
\hline 41 & & & & & & & \\
\hline 42 & Q2 & & & & & & \\
\hline 43 & Labor an & laterial per & & & & & $\mathrm{c}$ \\
\hline 44 & Commis & per bearin & & & & & c \\
\hline 45 & Hence, $u$ & variable co & $r$ bearing or & & & & c \\
\hline 46 & & & & & & & \\
\hline 47 & Q3 & & & & & & \\
\hline 48 & Therefor & or UVCM & bearing & & & & c \\
\hline 49 & and $\% \mathrm{C}$ & VCM per $\mathrm{b}$ & & & & & c \\
\hline 50 & & & & & & & \\
\hline 51 & Q4 & & & & & & \\
\hline 52 & Producti & un setup & & & & & c \\
\hline 53 & Salesfor & alary & & & & & c \\
\hline 54 & Salesfor & ravel & & & & & $\mathrm{c}$ \\
\hline 55 & Advertisi & and promot & & & & & c \\
\hline 56 & Total Dir & Fixed Cost & hout profit o & ctive & & & $\mathrm{c}$ \\
\hline 57 & & & & & & & \\
\hline 58 & Q5 & & & & & & \\
\hline 59 & \# BEP, v & out profit ob & ve, rounded & & & & $\mathrm{c}$ \\
\hline 60 & $\$ B E P, v$ & out profit ob & & & & & $\mathrm{c}$ \\
\hline 61 & & & & & & & \\
\hline 62 & Q6 & & & & & & \\
\hline 63 & Total Dir & Fixed cost & h profit obje & & & & $\mathrm{c}$ \\
\hline 64 & & & & & & & \\
\hline 65 & Q7 & & & & & & \\
\hline 66 & \# RLS, n & profit objec & rounded up & & & & $\mathrm{c}$ \\
\hline 67 & $\$ R L S, n$ & profit objec & & & & & $\mathrm{c}$ \\
\hline
\end{tabular}


Exhibit 2c: Excel Solution Sheet for a Typical Case-let (this is available to students)

\begin{tabular}{|c|c|c|c|c|c|c|c|c|}
\hline & A & B & C & D & $\mathrm{E}$ & $\mathrm{F}$ & & G \\
\hline 1 & \multicolumn{3}{|c|}{ Texas Bearing Company } & & & & & \\
\hline 2 & \multicolumn{5}{|c|}{ Illustration of breakeven analysis without and with profit } & & & \\
\hline 3 & \multicolumn{5}{|c|}{ worksheet created by: Dr. Gopala Ganesh, UNT, Denton, Texas } & & & \\
\hline \multicolumn{9}{|l|}{4} \\
\hline 5 & \multicolumn{2}{|c|}{ INPUTS SECTION } & & & & & & \\
\hline 6 & & & & & & & & \\
\hline 7 & \multicolumn{3}{|c|}{ Information on Prices and Margins: } & & & & & \\
\hline 8 & & & & & & & & \\
\hline 9 & \multicolumn{3}{|c|}{ Retail Price of a typical TBC Bearing } & & & & $\$$ & 32.00 \\
\hline 10 & \multicolumn{4}{|c|}{ Average retailer $\%$ markup on selling price } & & & & $40.00 \%$ \\
\hline 11 & \multicolumn{4}{|c|}{ Wholesale $\%$ distributor markup on cost } & & & & $33.00 \%$ \\
\hline 12 & & & & & & & & \\
\hline 13 & Informat & n Variable & & & & & & \\
\hline 14 & & & & & & & & \\
\hline 15 & Labor ar & aterial Cos & Each Bearing & & & & $\$$ & 9.48 \\
\hline 16 & Sales R & sentative C & mission \% & & & & & $5.00 \%$ \\
\hline 17 & & & & & & & & \\
\hline 18 & Informat & n Fixed $\mathrm{Cc}$ & & & & & & \\
\hline 19 & & & & & & & & \\
\hline 20 & Producti & etup & & & & & $\$$ & $13,650.00$ \\
\hline 21 & Salespe & Salary & & & & & $\$$ & $36,000.00$ \\
\hline 22 & Salespe & Travel Sup & & & & & $\$$ & $9,000.00$ \\
\hline 23 & Cost of & rtising and & les Promotion & & & & $\$$ & $6,000.00$ \\
\hline 24 & & & & & & & & \\
\hline 25 & Informat & Profit Goa & & & & & & \\
\hline 26 & & & & & & & & \\
\hline 27 & Expecte & ntribution $\mathrm{t}$ & largin & & & & $\$$ & $37,000.00$ \\
\hline 28 & & & & & & & & \\
\hline 29 & Informat & Other & & & & & & \\
\hline 30 & & & & & & & & \\
\hline 31 & Number & eld Sales & resentatives & & & & & 2 \\
\hline 32 & & & & & & & & \\
\hline 33 & OUTPU & ECTION & & & & & & \\
\hline 34 & & & & & & & & \\
\hline 35 & Q1 & & & & & & & \\
\hline 36 & Retailer' & ling price $p$ & pearing & & & & $\$$ & 32.00 \\
\hline 37 & Retailer' & t price per & aring & & & & $\$$ & 19.20 \\
\hline 38 & Wholese & elling price & r bearing & & & & $\$$ & 19.20 \\
\hline 39 & Wholese & & & & & & $\$$ & 14.44 \\
\hline 40 & Hence, & (manufactı & selling price & er bearing & & & $\$$ & 14.44 \\
\hline 41 & & & & & & & & \\
\hline 42 & Q2 & & & & & & & \\
\hline 43 & Labor ar & aterial per & ring & & & & $\$$ & 9.48 \\
\hline 44 & Commis & per bearin & & & & & $\$$ & 0.72 \\
\hline 45 & Hence, & ariable cos & er bearing or & & & & $\$$ & 10.20 \\
\hline 46 & & & & & & & & \\
\hline 47 & Q3 & & & & & & & \\
\hline 48 & Therefor & or UVCM & bearing & & & & $\$$ & 4.23 \\
\hline 49 & and $\% \mathrm{C}$ & VCM per b & & & & & & $29.33 \%$ \\
\hline 50 & & & & & & & & \\
\hline 51 & Q4 & & & & & & & \\
\hline 52 & Producti & in setup & & & & & $\$$ & $13,650.00$ \\
\hline 53 & Salesfor & alary & & & & & $\$$ & $72,000.00$ \\
\hline 54 & Salesfor & avel & & & & & $\$$ & $18,000.00$ \\
\hline 55 & Advertis & nd promoti & & & & & $\$$ & $6,000.00$ \\
\hline 56 & Total Di & Fixed Costs & thout profit ob & ctive & & & $\$$ & $109,650.00$ \\
\hline 57 & & & & & & & & \\
\hline 58 & Q5 & & & & & & & \\
\hline 59 & \# BEP, & ut profit ob & tive, rounded & & & & & 25,896 \\
\hline 60 & $\$ B E P$, & ut profit ob & & & & & $\$$ & $373,836.99$ \\
\hline 61 & & & & & & & & \\
\hline 62 & Q6 & & & & & & & \\
\hline 63 & Total Di & -ixed costs & ith profit objec & & & & $\$$ & $146,650.00$ \\
\hline 64 & & & & & & & & \\
\hline 65 & Q7 & & & & & & & \\
\hline 66 & \# RLS, v & rofit object & , rounded up & & & & & 34,634 \\
\hline 67 & $\$$ RLS, v & rofit object & & & & & $\$$ & $499,979.55$ \\
\hline
\end{tabular}


Exhibit 2d: Excel Formula Sheet for a Typical Case-let (this is NOT available to students)

\begin{tabular}{|c|c|c|}
\hline & A & $\mathrm{G}$ \\
\hline 1 & Texas Bearing Company & \\
\hline 2 & IIlustration of breakeven analysis without and with profit & \\
\hline 3 & worksheet created by: Dr. Gopala Ganesh, UNT, Denton, Texas & \\
\hline \multicolumn{3}{|l|}{4} \\
\hline 5 & INPUTS SECTION & \\
\hline \multicolumn{3}{|c|}{\begin{tabular}{l|l}
6 & \\
\end{tabular}} \\
\hline 7 & Information on Prices and Margins : & \\
\hline \multicolumn{3}{|l|}{8} \\
\hline 9 & Retail Price of a typical TBC Bearing & 32 \\
\hline 10 & Average retailer $\%$ markup on selling price & 0.4 \\
\hline 11 & Wholesale $\%$ distributor markup on cost & 0.33 \\
\hline \multicolumn{3}{|l|}{12} \\
\hline \multicolumn{3}{|c|}{\begin{tabular}{l|l}
13 & Information on Variable Costs : \\
\end{tabular}} \\
\hline \multicolumn{3}{|l|}{14} \\
\hline 15 & Labor and Material Cost of Each Bearing & 9.48 \\
\hline 16 & Sales Representative Commission \% & 0.05 \\
\hline \multicolumn{3}{|c|}{\begin{tabular}{l|l}
17 & 1 \\
\end{tabular}} \\
\hline \multicolumn{3}{|c|}{\begin{tabular}{l|l}
18 & Information on Fixed Costs: \\
\end{tabular}} \\
\hline \multicolumn{3}{|l|}{19} \\
\hline 20 & Production Setup & 13650 \\
\hline 21 & Salesperson Salary & 36000 \\
\hline 22 & Salesperson Travel Support & 9000 \\
\hline 23 & Cost of Advertising and Sales Promotion & 6000 \\
\hline \multicolumn{3}{|c|}{24} \\
\hline 25 & Information : Profit Goal & \\
\hline \multicolumn{3}{|l|}{26} \\
\hline 27 & Expected Contribution to Margin & 37000 \\
\hline \multicolumn{3}{|c|}{\begin{tabular}{l|l}
28 & 1 \\
\end{tabular}} \\
\hline 29 & Information: Other & \\
\hline \multicolumn{3}{|l|}{30} \\
\hline 31 & Number of Field Sales Representatives & 2 \\
\hline \multicolumn{3}{|l|}{32} \\
\hline 33 & OUTPUTS SECTION & \\
\hline 34 & & \\
\hline 35 & Q1 & \\
\hline 36 & Retailer's selling price per bearing & $=\mathrm{G} 9$ \\
\hline 37 & Retailer's cost price per bearing & $=G 36^{*}(1-G 10)$ \\
\hline 38 & Wholesaler selling price per bearing & $=\mathrm{G} 37$ \\
\hline 39 & Wholesaler Cost & $=\mathrm{G} 38 /(1+\mathrm{G} 11)$ \\
\hline 40 & Hence, TBC (manufacturer) selling price per bearing & $=\mathrm{G} 39$ \\
\hline 41 & & \\
\hline 42 & Q2 & \\
\hline 43 & Labor and material per bearing & $=\mathrm{G} 15$ \\
\hline 44 & Commission per bearing & $=\mathrm{G} 16 * \mathrm{G} 40$ \\
\hline 45 & Hence, unit variable cost per bearing or UVC & $=\mathrm{SUM}(\mathrm{G} 43: \mathrm{G} 44)$ \\
\hline 46 & & \\
\hline 47 & Q3 & \\
\hline 48 & Therefore $\$ \mathrm{C}$ or UVCM per bearing & $=$ G40-G45 \\
\hline 49 & and $\% \mathrm{C}$ or $\mathrm{PVCM}$ per bearing & $=\mathrm{G} 48 / \mathrm{G} 40$ \\
\hline 50 & & \\
\hline 51 & Q4 & \\
\hline 52 & Production run setup & $=\mathrm{G} 20$ \\
\hline 53 & Salesforce salary & $=\mathrm{G} 21^{*} \mathrm{G} 31$ \\
\hline 54 & Salesforce travel & $=\mathrm{G} 22 * \mathrm{G} 31$ \\
\hline 55 & Advertising and promotion & $=\mathrm{G} 23$ \\
\hline 56 & Total Direct Fixed Costs without profit objective & $=$ SUM(G52:G55) \\
\hline 57 & & \\
\hline 58 & Q5 & \\
\hline 59 & \# BEP, without profit objective, rounded up & $=$ ROUNDUP(G56/G48,0 \\
\hline 60 & \$ BEP, without profit objective & $=\mathrm{G} 59 * \mathrm{G} 40$ \\
\hline 61 & & \\
\hline 62 & Q6 & \\
\hline 63 & Total Direct Fixed costs, with profit objective & $=G 56+G 27$ \\
\hline 64 & & \\
\hline 65 & Q7 & \\
\hline 66 & \# RLS, with profit objective, rounded up & $=$ ROUNDUP(G63/G48,0 \\
\hline 67 & \$ RLS, with profit objective & $=\mathrm{G} 66^{*} \mathrm{G} 40$ \\
\hline
\end{tabular}

